\title{
Homme/milieu dans le bassin versant de la Briance depuis les débuts de la métallurgie
}

\section{Patrice Wuscher}

\section{(QpenEdition Journals}

Édition électronique

URL : http://journals.openedition.org/adlfi/7978

ISSN : 2114-0502

Éditeur

Ministère de la culture

Référence électronique

Patrice Wuscher, « Homme/milieu dans le bassin versant de la Briance depuis les débuts de la métallurgie ", ADLFI. Archéologie de la France - Informations [En ligne], Limousin, mis en ligne le 01 mars 2005, consulté le 20 avril 2019. URL : http://journals.openedition.org/adlfi/7978

Ce document a été généré automatiquement le 20 avril 2019

(c) Ministère de la Culture et de la Communication, CNRS 


\title{
Homme/milieu dans le bassin versant de la Briance depuis les débuts de la métallurgie
}

\author{
Patrice Wuscher
}

Identifiant de l'opération archéologique : 122373

Date de l'opération : 2005 (PT)

1 Après une année d'interruption, cette opération s'est poursuivie en 2005. Tout comme en 2003, les recherches se sont concentrées sur le bassin versant de la Ligouré, compris dans les communes de Saint-Jean-Ligouré et de Saint-Priest-Ligouré.

Initialement, était posée la question du paysage agricole dans lequel s'inscrivaient les sites protohistoriques et médiévaux de Chalucet. Les pistes explorées cette année étaient plus pragmatiques. Ainsi, une grande partie des cadastres napoléoniens a été numérisée. Sur le terrain, les sites étudiés à Saint-Jean-Ligouré lors du PCR « Archéologie agraire en Limousin » (1996, responsable : Ph. Allée) ont été revisités pour relever systématiquement tous les ouvrages hydrauliques fossiles, mentionnés ou non sur les cartes anciennes. En outre, pour la commune de Saint-Priest, de nouvelles coupes naturelles ont été recherchées. Enfin, des carottages manuels ont été tentés.

3 À l'issue de cette campagne, deux anciens moulins, deux étangs abandonnés et un bassin ont été inventoriés. Ces ouvrages démontrent une nouvelle fois l'ampleur de l'anthropisation des cours d'eau limousins aux périodes médiévales et des Temps Modernes.

Cependant, comme l'avait déjà montré le PCR «Archéologie agraire en Limousin », ces cours d'eau n'ont pas toujours eu cette configuration et ont subi une histoire quelque peu mouvementée. C'est ce que semble montrer la série de coupes étudiée en aval du bourg de Saint-Priest-Ligouré.

WUSCHER Patrice 
INDEX

operation Prospection thématique (PRT)

Thèmes : agriculture, bassin sédimentaire, cadastre, carte, cours d'eau, enregistrementdiffusion, étang, étude du paysage, hydraulique, moulin, sources écrites

Index chronologique : ép. contemporaine, Moyen Âge*, Protohistoire, Temps Modernes Index géographique : Limousin, Haute-Vienne (87), Saint-Jean-Ligoure

\section{AUTEURS}

PATRICE WUSCHER

BEN 